\title{
FEASIBILITY OF STAKEHOLDER MANAGEMENT TO IMPROVE INTEGRATION AND COMMUNICATION USING BIG ROOM, LEAN CONSTRUCTION, PMBOK AND PRINCE2 IN MULTIFAMILY PROJECTS IN TIMES OF CHANGE
}

\author{
Alvaro A. Sosa ${ }^{1}$ and Jorge R. De La Torre ${ }^{2}$
}

\begin{abstract}
The purpose of this article is to corroborate the feasibility of stakeholder management for multifamily projects using Big Room as the main tool and Lean Construction, PMBOK6 and PRINCE2 as management methodologies. In Peru, multifamily projects have a great lack of integration and communication between stakeholders in all phases of execution. For this purpose, a survey was conducted among engineers with expertise in construction project management with emphasis on stakeholder management and a comparative technical analysis to highlight the best of each methodology. Finally, a stakeholder management proposal was developed taking into account these changing times due to the pandemic.
\end{abstract}

\section{KEYWORDS}

Lean construction, big room, integration, management.

\section{INTRODUCTION}

Multifamily housing construction requires a well-structured management strategy by all stakeholders for the success of the project. Therefore, the problems that arise from inefficient construction project management are innumerable and must be detected and corrected in a timely manner. In addition, the paralysis of the construction sector due to the pandemic symbolized an economic downturn that was detrimental to all stakeholders involved (Zhang, X., Hou, H., Fu, Q. and Zhang, Y. , 2020). This refers to the group of people who are impacted by the company's decisions. Its management is very scarce in the construction of multifamily projects in Peru, and many reports point out that part of the problem is due to the fact that a specific plan is not prepared for the stakeholders (Vacanas, Y., Danezis, C, 2021) to know what each one is looking for and to set common objectives for the success of the project.

Bachelor of School of Civil Engineering, Universidad Peruana de Ciencias Aplicadas, Lima, Peru, +51 995904 426, u201518172@upc.edu.pe, orcid.org/0000-0002-1324-6865

2 Magister Civil Engineer, Universidad Peruana de Ciencias Aplicadas, Lima, Peru, +51 975355 556, pccijdel@upc.edu.pe, orcid.org/0000-0003-3596-8196 
Although there are many processes involved in a multifamily project and multiple conditions that one may face, it is essential to practice good management from the beginning, as well as strict control and methodical planning based on the concepts of different institutions (Matos, M., 2018).

The objective of this article is to elaborate a stakeholder management proposal to improve integration and communication using Lean Construction, "Project Management Body of Knowledge" (PMBOK 6) and "Projects in Controlled Environments" (PRINCE2) by implementing the Big Room and adapting to the stages of the construction of a multifamily project considering the limitations and health constraints that have been established in Peru due to the pandemic with the following study methodology (Figure $1)$.

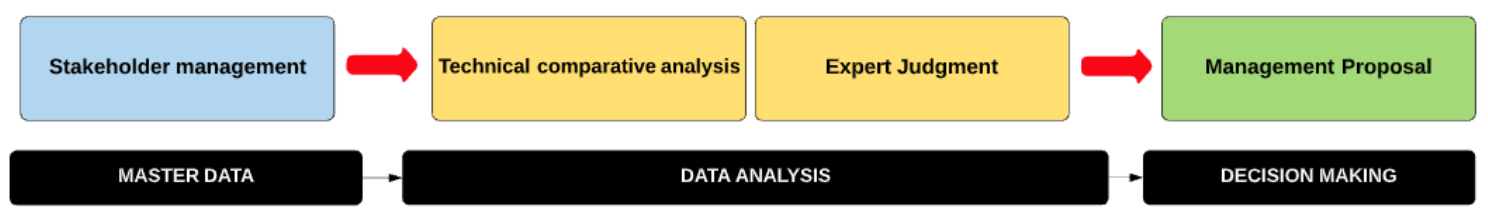

Figura 1: Study methodology flowchart.

\section{STUDY METHODOLOGY}

\section{MASTER DATa}

The information was gathered from three main sources: Lean Construction, PMBOK6 and PRINCE2. To begin with, Lean Construction has two integrative techniques that is based on how stakeholders work for project delivery which means a new method of designing and constructing buildings and infrastructure (Pons, J., and Lezana, E. 2014). On the other hand, PMBOK 6, latest edition of PMI knowledge guide (PMI, 2017), provides great inputs on management strategies. Finally, PRINCE2 is one of the most important methodologies of the APM, a British institution specialized in the accreditation or certification of organizations in the field of project management (Pico, O., 2016). Figure 2 shows the stakeholder management structure of each one.

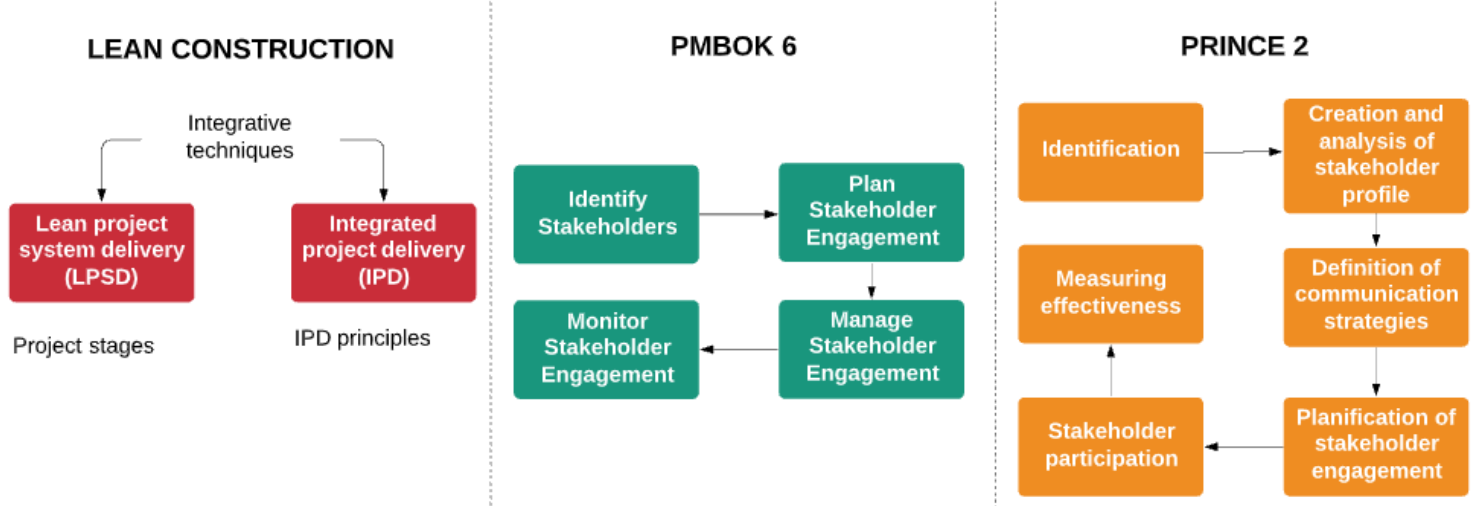

Figure 2: Stakeholder management structure of Lean Construction, PMBOK 6 and PRINCE2. 


\section{DATA ANALYSIS}

A technical comparative table was made to see what each one contributes to stakeholder management. For this occasion, the table (Table 1) was prepared based on the research proposal that consists of three phases, which are as follows:

1. Identification of stakeholders

2. Stakeholder management planning

3. Execution of stakeholder management

Table 1: Technical comparative analysis

\begin{tabular}{|c|c|c|c|}
\hline Phase & Lean Construction & PMBOK 6 & PRINCE 2 \\
\hline 1 & $\begin{array}{l}\text { LPSD concisely defines } \\
\text { the client's propositions } \\
\text { and the interests of all } \\
\text { stakeholders }\end{array}$ & $\begin{array}{l}\text { The charter project is a } \\
\text { source of information } \\
\text { that identifies and } \\
\text { analyzes the impact of } \\
\text { each stakeholder on the } \\
\text { project. }\end{array}$ & $\begin{array}{l}\text { The identification, } \\
\text { creation and analysis } \\
\text { of profiles is where } \\
\text { the roles and } \\
\text { responsibilities of each } \\
\text { person are defined. }\end{array}$ \\
\hline 2 & $\begin{array}{l}\text { The IPD principles are } \\
\text { promoted for good } \\
\text { communication between } \\
\text { each of the stakeholders. } \\
\text { In addition, the } \\
\text { organizational structure is } \\
\text { planned in a manner } \\
\text { consistent with the needs } \\
\text { and constraints of each } \\
\text { stakeholder. }\end{array}$ & $\begin{array}{l}\text { The project } \\
\text { management plan is } \\
\text { presented in which } \\
\text { approaches are } \\
\text { developed using } \\
\text { techniques and tools to } \\
\text { involve stakeholders in } \\
\text { their needs, } \\
\text { expectations and } \\
\text { interests. }\end{array}$ & $\begin{array}{l}\text { Stakeholder } \\
\text { participation is } \\
\text { planned here by } \\
\text { defining } \\
\text { communication } \\
\text { methods and } \\
\text { strategies to } \\
\text { encourage the } \\
\text { involvement of all } \\
\text { stakeholders. }\end{array}$ \\
\hline 3 & $\begin{array}{l}\text { An efficient } \\
\text { communications plan and } \\
\text { the practice of IPD } \\
\text { principles is fundamental } \\
\text { to the involvement of all } \\
\text { stakeholders. }\end{array}$ & $\begin{array}{l}\text { Incidents, changes, } \\
\text { lessons learned are } \\
\text { addressed to } \\
\text { encourage appropriate } \\
\text { participation by } \\
\text { everyone }\end{array}$ & $\begin{array}{l}\text { The communication } \\
\text { and stakeholder } \\
\text { involvement plan is } \\
\text { carried out at all } \\
\text { stages of project } \\
\text { implementation. }\end{array}$ \\
\hline
\end{tabular}

Finally, a survey was conducted among experienced engineers and experts in the field of project management in buildings to analyze the problem in Peru and corroborate the feasibility of the research topic. Given the pandemic we are going through, this expert judgment (Figure $3 \& 4$ ) was adapted as a virtual tool using the QuestionPro platform. Expert judgment is one of the most requested and used tools in construction project management, since it allows me to corroborate all kinds of information with a certain degree of uncertainty through the opinion and support of at least 10 experts for the validity of a problem (Galicia, L., Balderrama, J. and Edel, R., 2017), so a technical survey was conducted to the experts who are 14 civil engineers. 

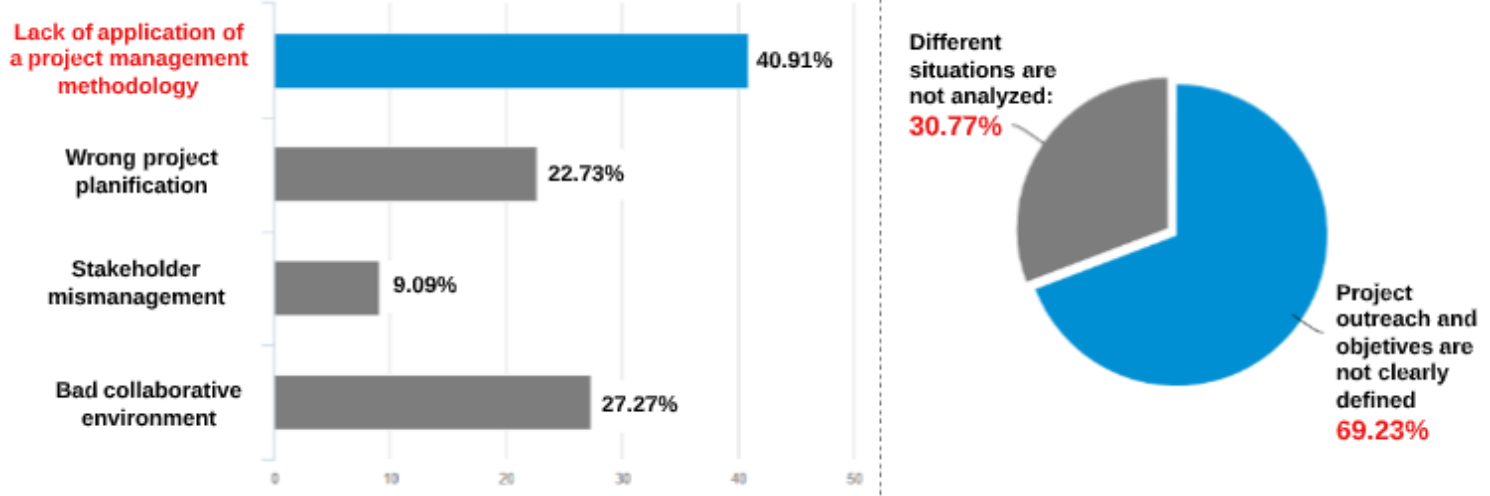

Figure 3: Most recurrent causes of inefficient multifamily project management and main problems in project planning in Peru. Adapted from QuestionPro.
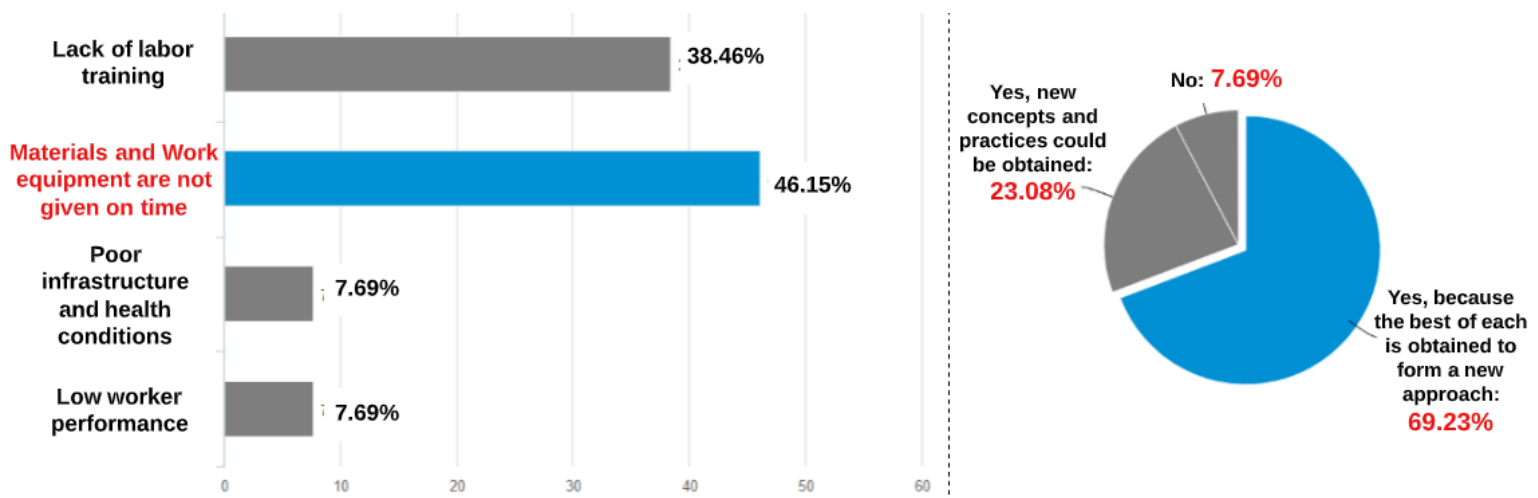

Figure 4: Reasons for poor on-site execution in multifamily projects in Peru and the percentage of feasibility of the subject of this article. Adapted from QuestionPro.

It is worth mentioning that the technical survey consisted of 16 questions, but, for the purposes of this article, only four of the most important questions were selected.

\section{DECISION MAKING}

The stakeholder management proposal is aimed at multifamily projects. Therefore, the stages of this type of projects are shown (Figure 5).

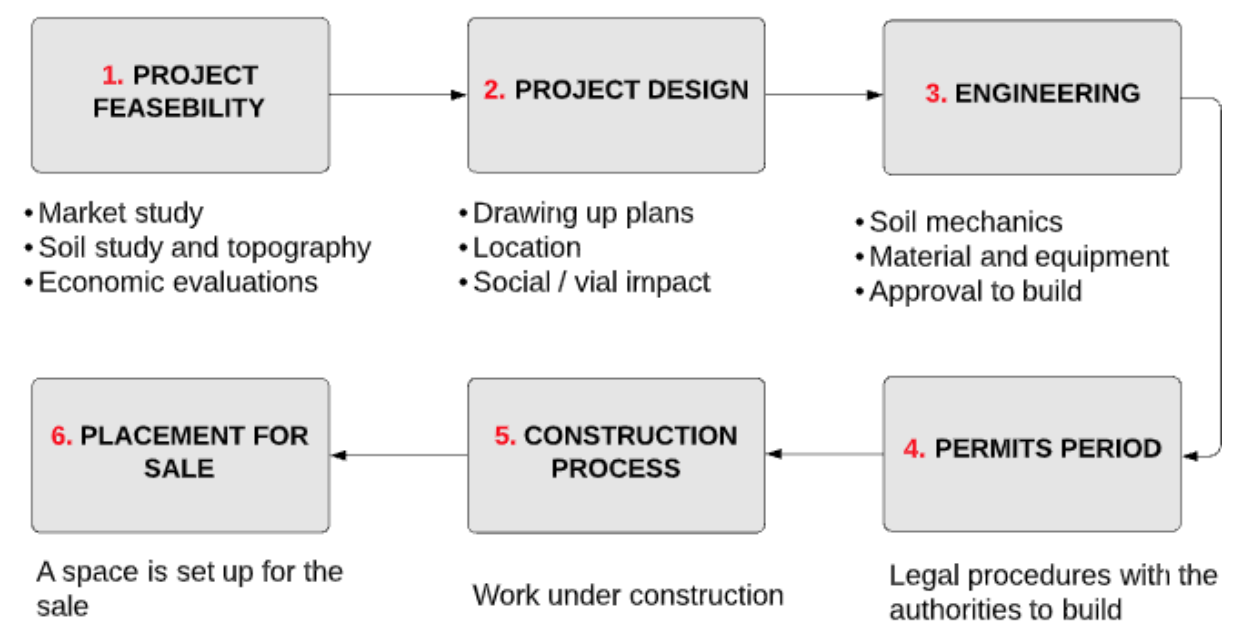

Figure 5: Stages in the construction of a multifamily project. 
The following is a detailed explanation of the proposal that focuses on stakeholder management with the integration of the aforementioned study methodologies.

\section{Stakeholder identification}

Figure 6 shows the structure of the initial phase, which consists of the activities or documents to be carried out. For that, some techniques and tools are used to fulfill everything structured and move on to the next phase.

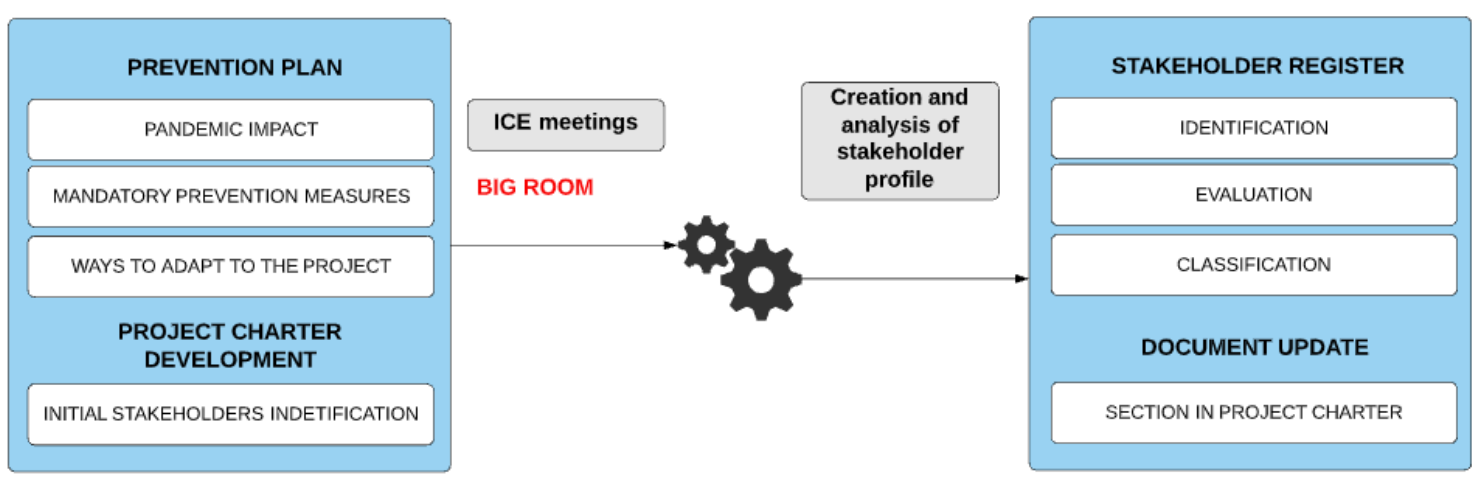

Figure 6: Structure of the stakeholder identification phase.

This phase is very important before starting with the feasibility stage of a multifamily project, since before any type of study is carried out, it is necessary to know who the team members are and what their intentions and expectations are within the project. For that, it is established to have a specific section in the project charter about the interested parties and to discuss about the new prevention measures that one has to comply with in order to work with the lowest possible risk, since the world is facing a pandemic with a very high mortality rate.

To achieve a correct registration of stakeholders, it is established to implement ICE meetings, since one of the objectives of Lean Construction is to improve the levels of collaboration. Therefore, integrated concurrent engineering (ICE) is a method that gives us an effective and reliable development of any type of engineering or design. Now, due to the pandemic, it is recommended, for this phase, to make use of the "Big Room" type of ICE meeting (Kunz, J. and Fischer, M., 2020).

Big Room is a large and orderly space that fosters a good collaborative environment. This is where the training and the elaboration of a profile of each interested party will take place, reflecting their knowledge, communication methods and their interest in the project.

2. Stakeholder management planning

An on-site prevention plan containing all of the components, shown in Figure 7, should be established to avoid any risk of pandemic infection. 


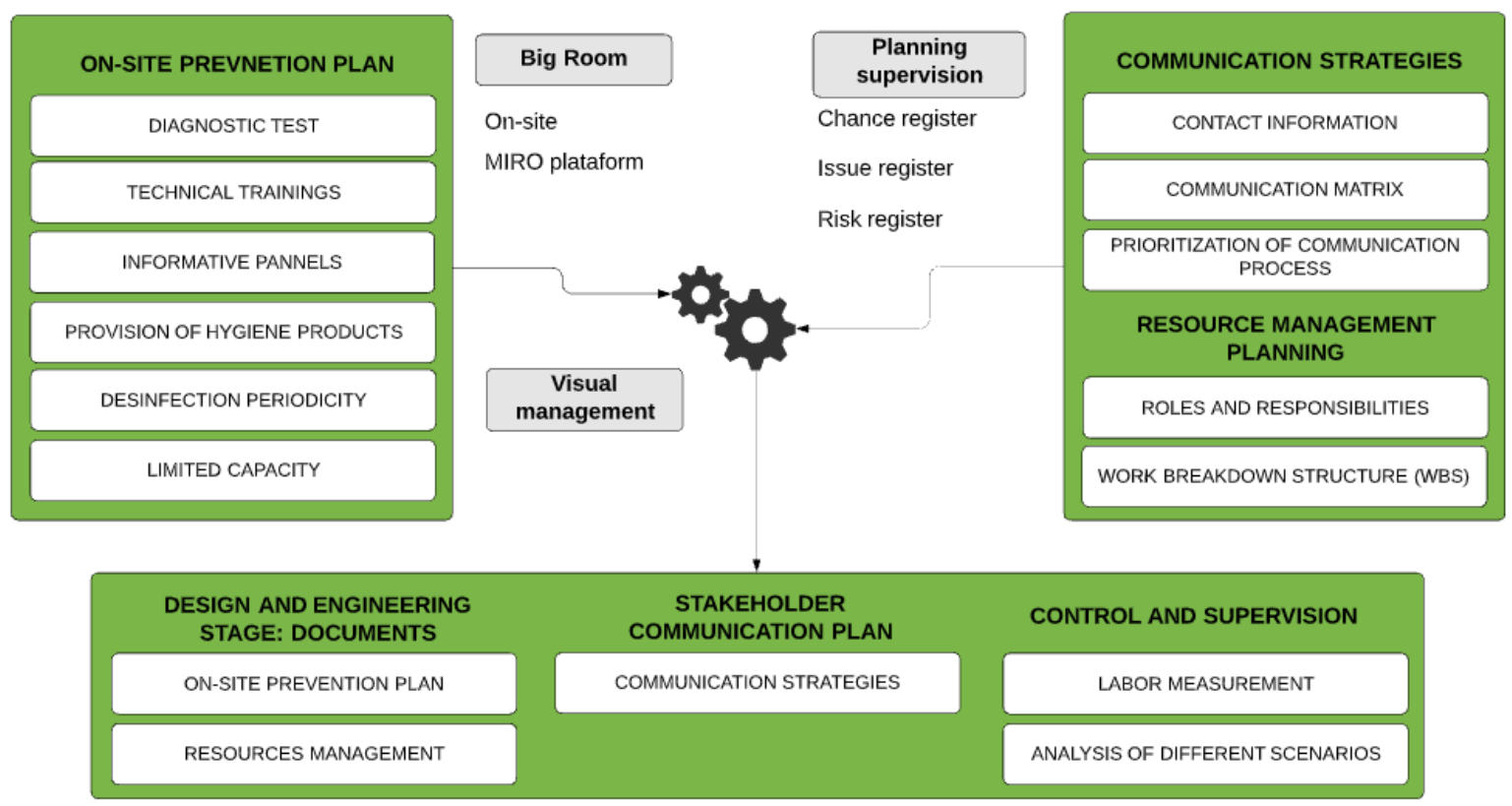

Figure 7: Structure of the stakeholder management planning phase.

For this, the organizational structure is elaborated, where it is seen who responds to whom and under what measures to avoid unnecessary meetings that raise the risk of contagion at work. Therefore, communication strategies must be defined (Figure 8), which contains contact information, a communication matrix and a degree of prioritization that helps the manager to maintain a fluid conversation with the engineer, designer, architect, main contractors and derivatives during the design and engineering stages.

\begin{tabular}{|c|c|c|}
\hline Contact information & Communication matrix & $\begin{array}{c}\text { Prioritization of } \\
\text { communication process }\end{array}$ \\
\hline $\begin{array}{l}\text { - Role in proyect } \\
\text { - Professional title } \\
\text { - E-mail } \\
\text { - Phone number }\end{array}$ & $\begin{array}{l}\text { - Required information } \\
\text { - Medium(virtual, face to face, } \\
\text { email) } \\
\text { - Target audience } \\
\text { - Information content } \\
\text { - Frecuency of contact }\end{array}$ & $\begin{array}{l}\text { - Type of information defined } \\
\text { - Decision-making authority } \\
\text { - Time established for a } \\
\text { resolution }\end{array}$ \\
\hline
\end{tabular}

Figure 8: Content of the register of communication strategies among stakeholders.

For the development of the activities of this phase, the progress of the project planning must continue with the practice of the Big room. For strictly necessary cases, it is carried out in person taking all sanitary measures. Otherwise, virtual meetings are implemented using the MIRO platform (Figure 9). 

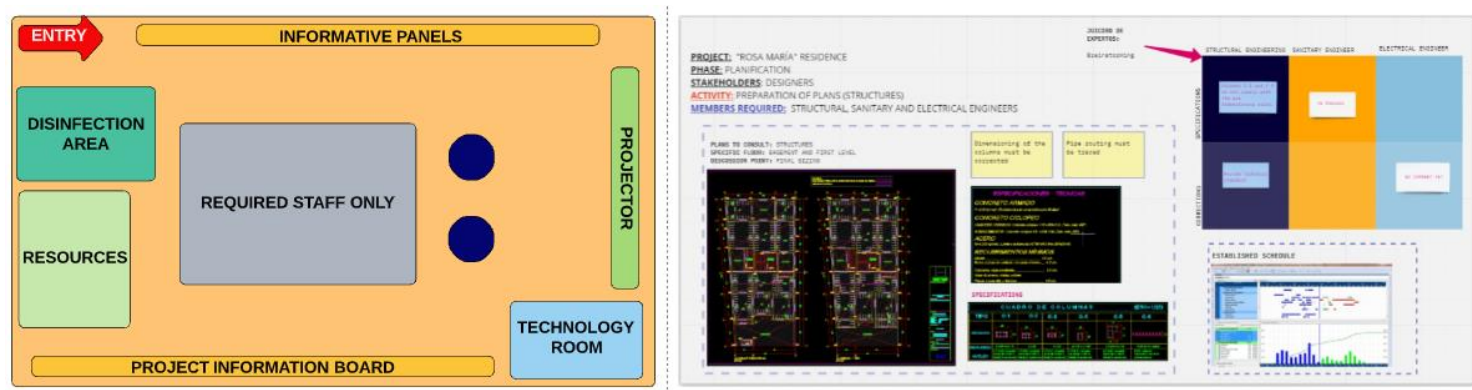

Figure 9: Proposed layout of the on-site Big Room and virtual Big Room using the MIRO platform.

MIRO facilitates the meeting between the design and engineering team to discuss planning decisions for on-site execution. In addition, the service is free, easy to access, and above all encourages the application of visual management, which is a Lean tool that helps clarify processes or other information to be visually appealing and simple to understand.

The novelty of this phase is that a control and follow-up is applied through a series of records mentioned in Figure 7, which helps to measure the work done in order to report any type of incident or risk, and make changes if necessary, taking into account different scenarios.

3. Execution of stakeholder management

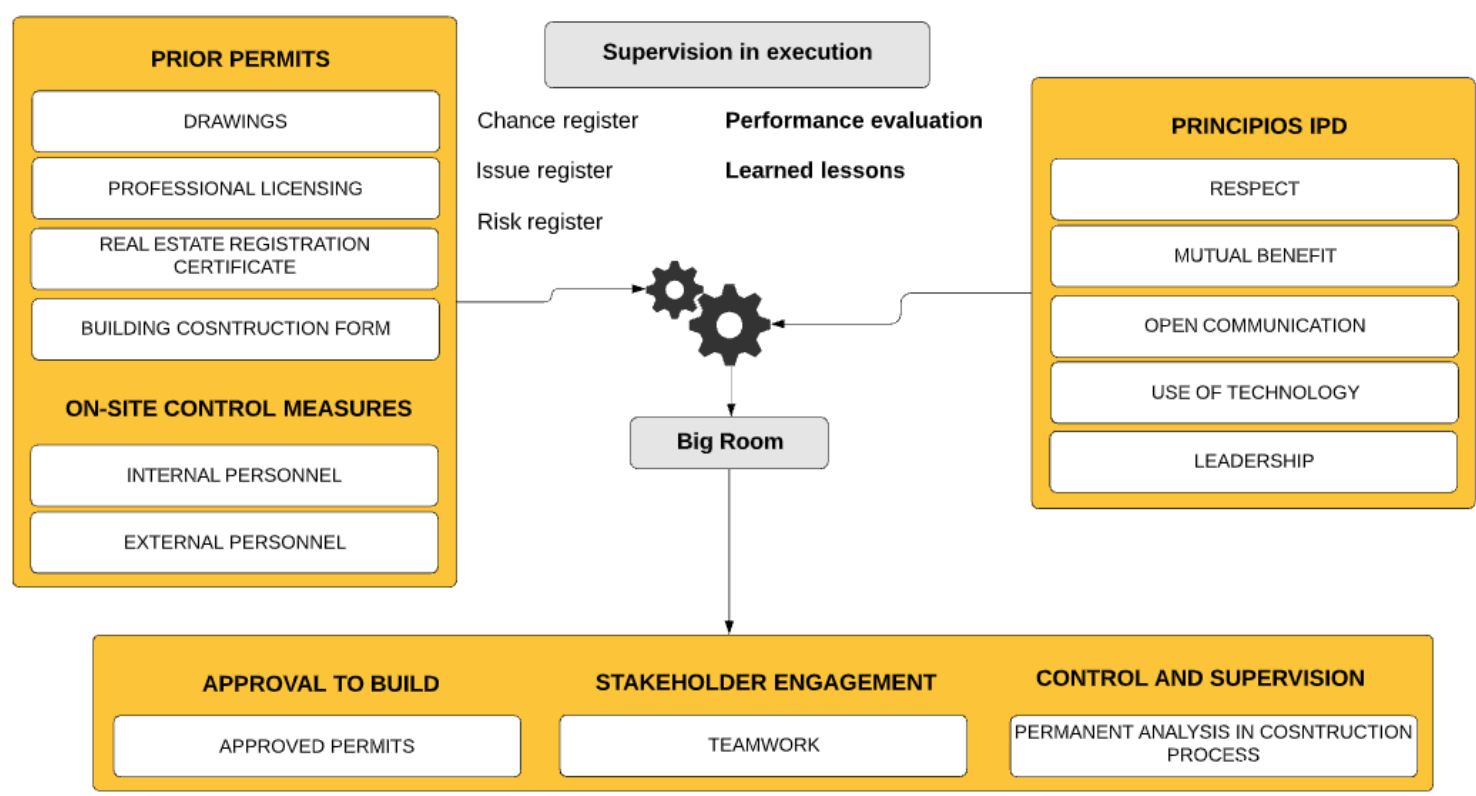

Figure 10: Structure of the execution phase of stakeholder management.

According to Figure 10, all documents must be in order since they must be reviewed by the district municipality of the project location in order to start the construction process without inconveniences.

Integrated Project Delivery (IPD) contains a series of very important principles for the correct execution of a construction project. The engineers interviewed emphasize that the poor collaborative environment that exists in construction companies is synonymous with poor management in Peru. Therefore, these principles help to form leaders regardless of the position one holds. Respect, good communication will foster a good working 
environment taking advantage of all the tools and technological availabilities mentioned above for a correct progress.

Everything planned in this pahse is put into practice and it is very important to comply with all the limitations set forth. Therefore, before entering the work site, a temperature control must be performed using a laser thermometer. Once this has been checked, the disinfection area must be entered, where water, soap and alcohol are required for hand and body hygiene. Finally, when leaving the disinfection area, latex masks and gloves must be provided, which must be renewed daily.
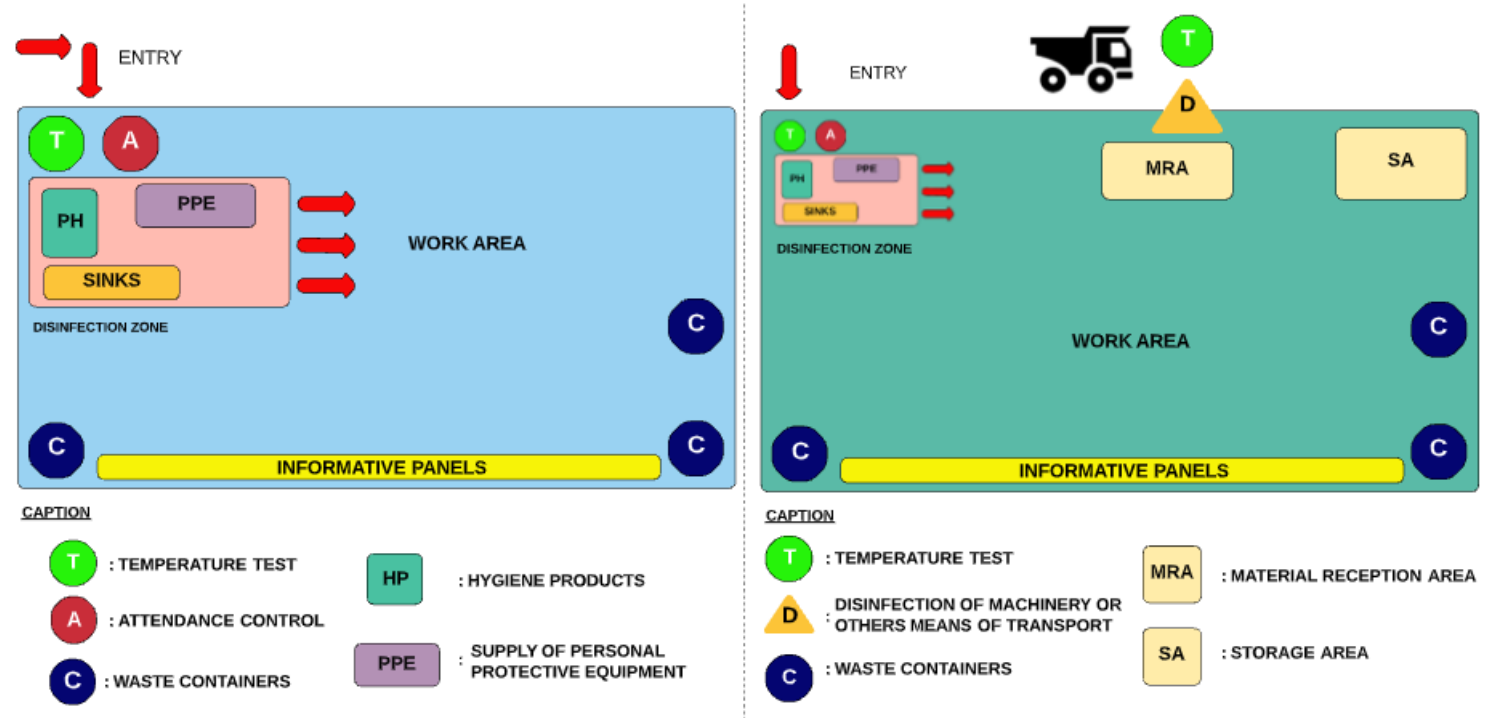

Figure 11: Proposed layout of the work area on site and layout of the materials reception area, applying preventive sanitary measures.

Figure 11 shows the proposed layout for the work areas. Now, for the internal personnel the following is established:

- Establish personnel in charge of disinfecting and cleaning work tools, materials and shared-use equipment.

- Establishment of maximum capacities in the different areas of the construction site.

- Inclusion of informative panels to make workers aware of the danger posed by the pandemic.

In the case of external personnel, the following must be complied with:

- Perform temperature control and ensure that they proceed to hand hygiene.

- Do not allow the entry of people who are not involved in the execution of activities during the working day.

- Encourage all types of documents to be delivered by digital means to ensure social distancing.

For the last stage of the construction process, a Big Room is proposed for the sales area, following the necessary sanitary measures (Figure 12). 


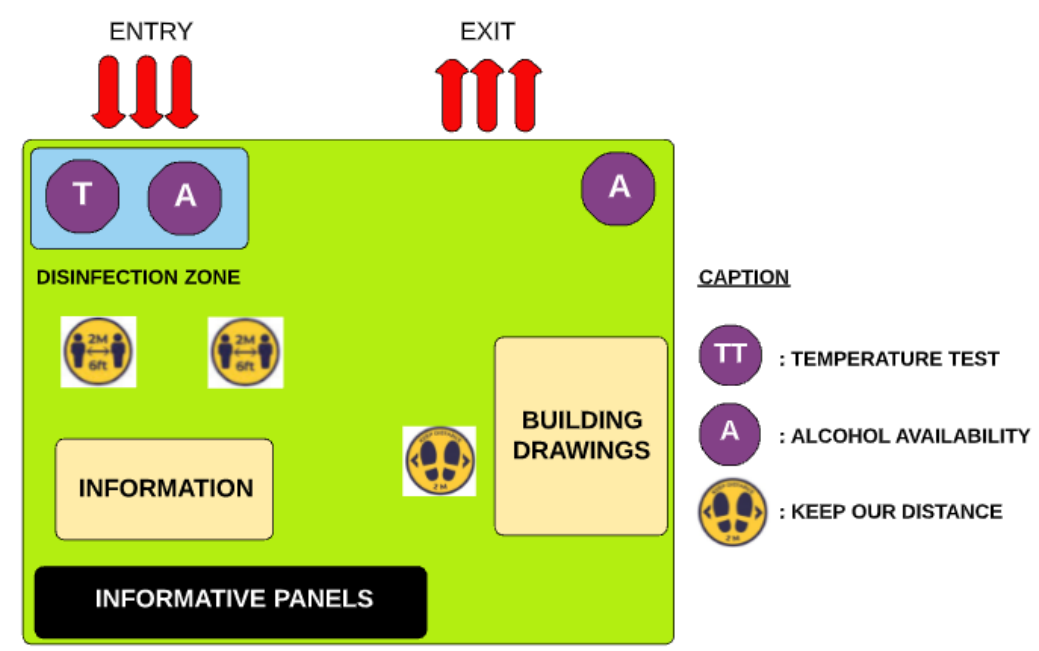

Figura 12: Proposed layout of sales area.

Finally, in this phase, monitoring and follow-up adds two records: Performance Evaluation and Lessons Learned. These reports help to evaluate the performance of the stakeholders and recognize which were the errors in the assigned activity with the objective to improve immediately and take into consideration these records for future planning of other multifamily projects.

\section{CONCLUSIONS}

The experts' opinion highlights the management problems in multifamily projects in Peru, mentioning that $68.18 \%$ of the causes of inefficient management are due to the lack of application of a project management methodology $(40.91 \%)$ and a poor collaborative environment (27.27\%).

Inefficient planning development and poor execution of a multifamily project in Peru is mainly due to project scope and objectives not being clearly and concisely defined (40.91\%) and equipment and work materials not being delivered on schedule (46.15\%) respectively.

In the three phases of the proposal, the practice of face-to-face and virtual Big Room (MIRO platform), type of ICE meeting, is established, since it promotes order and speed to make decisions in any situation that may occur during the development stages of a multifamily project.

The constant monitoring of the activities established in the proposal with the established records allows them to analyze the different scenarios during a multifamily project. That is, it helps to identify any type of incident or underperformance of the stakeholder to take corrective action quickly and effectively.

The stakeholder communication plan, shown in phase 2 of the proposal, represents the use of communication strategies in a registry that allow for greater fluidity and integration among each stakeholder.

The feasibility of stakeholder management in multifamily projects in Peru applying the mentioned methodologies and the use of the Big Room as the main tool is $92.31 \%$, since the best of each one is obtained (69.23\%) and new concepts and practices are established $(23.08 \%)$ to formulate a new approach in these times of change as stated in our proposal. 


\section{REFERENCES}

Galicia, L., Balderrama, J. and Edel, R. (2017). "Validez de contenido por juicio de expertos: propuesta de una herramienta virtual". Apertura (Guadalajara, Jal.), 9(2), 42-53. doi.org/10.32870/ap.v9n2.993.

Kunz, J. and Fischer, M. (2020). "Virtual design and construction, Construction Management and Economics", doi.org/10.1080/01446193.2020.1714068.

Matos, M. (2018). "Sistema de gestión de proyectos de construcción basado en la filosofía Lean y en el PMBOK para mejorar su productividad". (Tesis de Magister). Universidad Privada del Norte, Perú.

Pico, O. (2016). "Los stakeholders como actores estratégico-instrumentales en los proyectos de la nueva gestión pública". (Master interuniversitario en dirección de proyectos). Universidad de Oviedo, España.

Pons, J. and Lezana, E. (2014). “Introducción a Lean Construction”. Madrid: Fundación Laboral de la Construcción.

Project Management Institute (2017). "La guía de los fundamentos para la dirección de proyectos (Guía del PMBOK)". Newtown Square, PA. PMI sexta edición.

Vacanas, Y. and Danezis, C. (2021). "Determination of effective delay-avoidance practices in cosntruction projects". Journal of Legal Affairs and Dispute Resolution in Engineering and Construction, 13(1) doi.org/10.1061/(ASCE)LA.1943$\underline{4170.0000438}$.

Zhang, X., Hou, H., Fu, Q. and Zhang, Y. (2020). "Current Problems and Restructuring Suggestions for Smart City Construction: A Case Study on Fight Agaisnt COVID-19 in Several Chinese Cites”. ACM Internacional Conference Proceeding Series, 64-69. doi.org/10.1145/3414752.3414803. 